\title{
John Birks: Pioneer in quantitative palaeoecology
}

\author{
Richard W Battarbee,' Henry Lamb, ${ }^{2}$ Keith Bennett, ${ }^{3}$ \\ Mary Edwards, ${ }^{4}$ Anne E Bjune, ${ }^{5}$ Peter E Kaland, ${ }^{6}$ Björn E Berglund, ${ }^{7}$ \\ André F Lotter, ${ }^{8}$ Heikki Seppä, ${ }^{9}$ Kathy J Willis, ${ }^{6,10,11}$ \\ Ulrike Herzschuh ${ }^{12}$ and Hilary H Birks ${ }^{6}$
}

\section{Abstract}

We describe the career of John Birks as a pioneering scientist who has, over a career spanning five decades, transformed palaeoecology from a largely descriptive to a rigorous quantitative science relevant to contemporary questions in ecology and environmental change. We review his influence on students and colleagues not only at Cambridge and Bergen Universities, his places of primary employment, but also on individuals and research groups in Europe and North America. We also introduce the collection of papers that we have assembled in his honour. The papers are written by his former students and close colleagues and span many of the areas of palaeoecology to which John himself has made major contributions. These include the relationship between ecology and palaeoecology, late-glacial and Holocene palaeoecology, ecological succession, climate change and vegetation history, the role of palaeoecological techniques in reconstructing and understanding the impact of human activity on terrestrial and freshwater ecosystems and numerical analysis of multivariate palaeoecological data.
\end{abstract}

\section{Keywords}

climate change, ecosystem history, Holocene, late-glacial, numerical data analysis, palaeoecology, palaeolimnology

Received I5 September 2014; revised manuscript accepted 23 September 2014

\section{Introduction}

In this issue, we have assembled a collection of papers in honour of John Birks (Figure 1). The papers span many of the areas of palaeoecological science that John himself has pioneered. They are written by his former students and close colleagues.

John's scientific journey has extended across more than five decades since publishing his first paper at the age of 19 in the Proceedings of the Manchester Philosophical Society (Birks, 1964). Recently, he elegantly described this journey in his aptly titled autobiographical paper 'A diverse scientific life' (Birks, 2014), a paper that he was invited to write following his 'Lifetime Achievement Award' at the 12th International Paleolimnology Symposium in Glasgow, 2012.

Over his stellar career, he has been based in just two universities: Cambridge from 1963 to 1984, and Bergen, Norway, from 1984 to the present. Through his teaching and writing, he has been a principal architect of the transformation of palaeoecology from a narrative, largely descriptive science to a more rigorous quantitative science capable of contributing to questions in theoretical ecology, to the reconstruction of past ecosystems and to the understanding of global environmental problems of major societal interest, including pollution, biodiversity and climate change.

Here, we pay tribute to John Birks' career in pushing forward the frontiers of palaeoecology as seen through the eyes of John's wife, Hilary, and his past and present colleagues and students in Cambridge and Bergen and those of his major collaborators in London, Lund, Kingston, Bern and Utrecht, Helsinki, Oxford and Potsdam. We also summarise the papers that follow in this special issue.

\section{Birks and Birks}

Hilary Birks has shared in John's scientific life through the last 50 years. They married in 1966 . Hilary was 1 year ahead of John as an undergraduate in Cambridge, and they became friends at the

\footnotetext{
'University College London, UK

${ }^{2}$ Aberystwyth University, UK

${ }^{3}$ Queen's University, UK

${ }^{4}$ University of Southampton, UK

5 Uni Research Climate, Norway

6University of Bergen, Norway

7 University of Lund, Sweden

${ }^{8}$ Utrecht University, The Netherlands

'University of Helsinki, Finland

IOUniversity of Oxford, UK

I Royal Botanic Gardens Kew, UK

${ }^{12}$ Alfred Wegener Institute, Helmholtz Centre for Polar and Marine

Research, Research Unit Potsdam, Germany
}

\section{Corresponding author:}

Richard W Battarbee, Environmental Change Research Centre, Department of Geography, University College London, Gower St, London WCIE 6BT, UK

Email: r.battarbee@ucl.ac.uk 


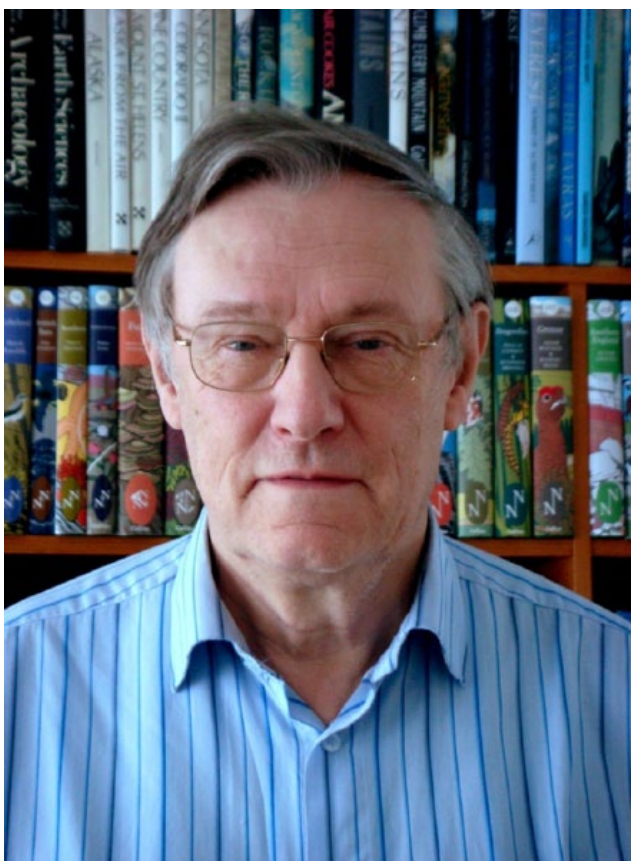

Figure I. John Birks in January 2010.

Source: Photo by Hilary H Birks.

1964 International Botanical Congress in Edinburgh. John had already developed an interest in pollen analysis and natural history while at school (Birks, 1964). Hilary was also interested in wild plants and became fascinated by Professor Sir Harry Godwin's lectures on vegetation history, such that she did her $\mathrm{PhD}$ on the vegetation history of Scotland using pollen analysis and pine stumps in peat. As John was working for his $\mathrm{PhD}$ on the late-glacial and modern vegetation of the Isle of Skye at the same time, they combined sediment coring with plant hunting and recording both flowering plants and bryophytes, in the Scottish Highlands and on Skye (e.g. Birks and Birks, 1974a, 1974b) over several field seasons. Their first botanical trip together was a student 'expedition' to Abisko in Swedish Lapland in 1965. Since then, they have enjoyed many expeditions studying alpine floras around the world, with plant photography becoming a major activity (Figure 2). Flora hunting led naturally to an awareness of and a strong interest in plant ecology. John combined ecology with palaeoecology in his $\mathrm{PhD}$ thesis (Birks, 1973) and became a palaeoecologist rather than a vegetation historian. During their post-doctoral year in Minnesota with Herb Wright and Ed Cushing, John became interested in the numerical analysis of palaeoecological data, while Hilary took up plant macrofossil analysis as a means of providing more precise information about which plants were forming vegetation communities near a site. Apart from their textbook (Birks and Birks, 1980), they have published relatively few joint papers, but recently, they have combined forces more frequently to promote new approaches to palaeoecology and palaeolimnology (Birks and Birks, 2004, 2006, 2008, 2013; Birks et al., 2000).

A sound knowledge of plant taxonomy and ecology has marked John's approach to his science. He has become expert in numerical data analysis, but for every method he has used, he has asked the questions 'Why am I doing this analysis? How will it help to address the problem in hand?' These questions have frequently required the development of novel methods and applications (Birks et al., 2012b). The combination of enthusiasm for his science, his formidable memory, a comprehensive collection of reprints and books, his encompassing knowledge of plant taxonomy and ecology and his numerical analytical expertise has made him an outstanding palaeoecologist. His enthusiasm and willingness to help others has inspired many over the years, and continues to this day, to the immense benefit to our science.
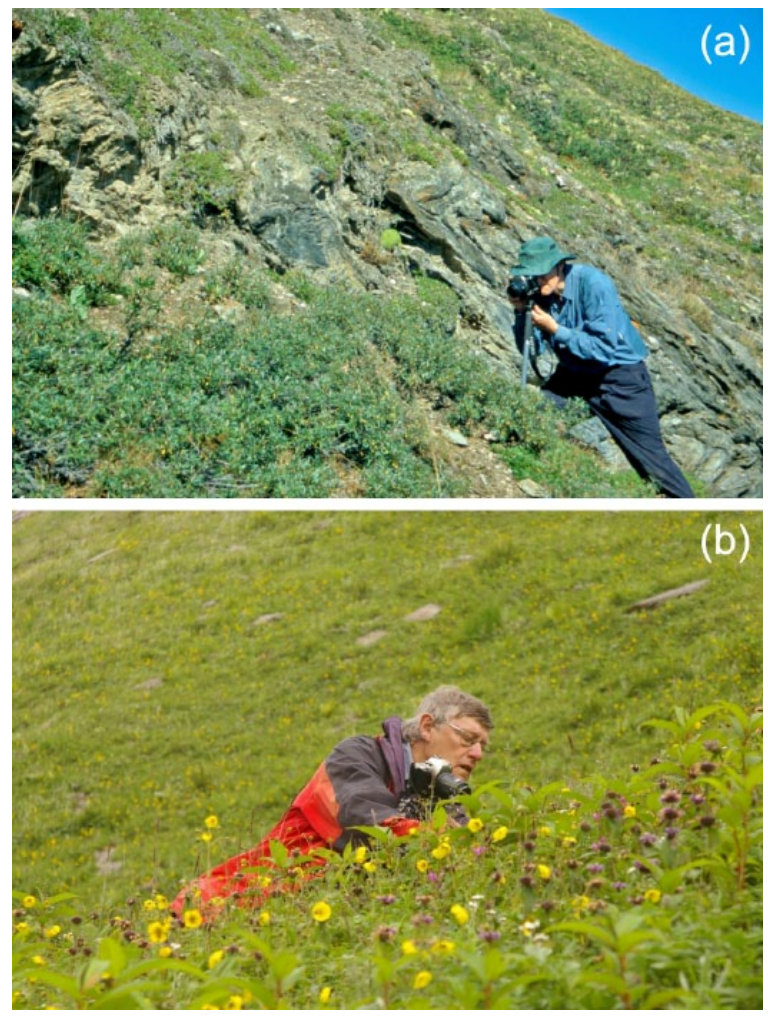

Figure 2. (a) John Birks photographing Hippophae rhamnoides at Høyrokampen in Bøverdalen, Lom (central Norway; photo by Anne Bjune, August 200I); (b) John Birks preparing to photograph a flower portrait in the species-rich alpine meadows on the Hampta Pass, Himachal Pradesh, NW India (photo by Hilary H Birks, July 2007).

\section{The Cambridge years}

John's Cambridge years span 1963-1984, including his time as undergraduate, $\mathrm{PhD}$ student and lecturer in the Botany School (now the Department of Plant Sciences; Birks, 2014). His PhD thesis (Birks, 1969, 1973) on the late-glacial vegetation of the Isle of Skye is one of the earliest palaeoecological studies to adopt an explicitly hypothesis-testing approach. Late-glacial vegetation history was also the subject of John's research during a post-doctoral year (1970) at the Limnological Research Center (LRC) in Minneapolis, Minnesota. His time in the LRC had a lasting influence on his life, as for so many others invited to work there by its director, Herb Wright. John took full advantage of the new contacts and research fields at the LRC to broaden his Cambridge horizons and become an international scientist. Besides the enduring influence and friendship of Herb Wright, Ed Cushing's analytical and thoughtful approach to ecology and vegetation history had a huge impact. Ed was exploring numerical analysis of pollen data to do among other things an objective zonation of pollen diagrams. This fascinated John and he rose to the challenge once back in Cambridge.

John returned to Cambridge as a post-doctoral Research Fellow at Sidney Sussex College, soon followed by election to a full Fellowship (1971), a position that required him to give tutorials ('supervisions' in Cambridge-speak) in botany and ecology to undergraduates. He was appointed a lecturer at the Botany School in 1975. His lectures were supported by cyclostyled reference lists, by far the longest and most detailed of the Botany School lecturers. He devised elegant practicals on the numerical phytogeography of pteridophytes, on Troels-Smith characterisation of sediments and on pollen analysis. Much of this material found its way into Birks and Birks (1980), a volume that is still so much in demand that it was reprinted in 2006. A 1977 'sonderheft' of The Tea Phytologist (Anonymous, 1977), a very occasional spoof journal of the Botany School, shows John as a member of an imaginary Botany School 


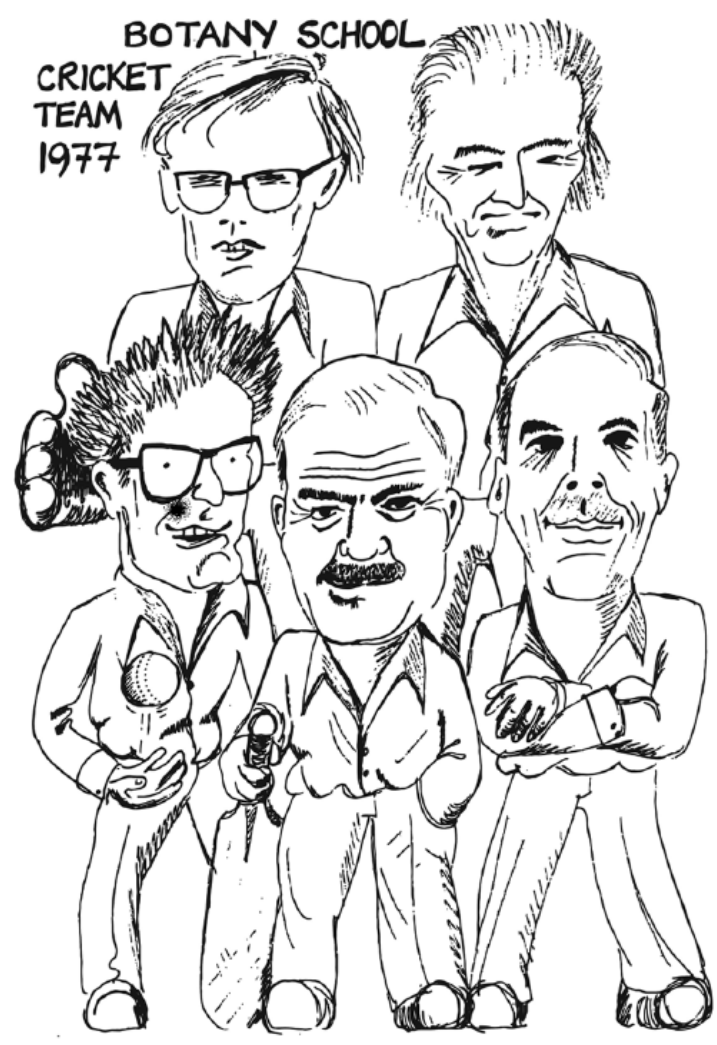

Figure 3. John Birks, top left, caricatured as a member of an imaginary Cambridge Botany School cricket team, in the Tea Phytologist of 1977 (Anonymous, 1977). Others depicted include (clockwise from top right) Max Walters, John Rishbeth, Percy Brian and David Briggs.

cricket team (Figure 3). His participation in the 6-week expedition to the St Elias Mountains, Yukon, in company with Herb and others in 1971, to study vegetational colonisation of glacial retreat moraines in space and time, was especially productive, resulting in some of the most cited publications from his Cambridge years (Birks, 1977a, 1980a, 1980c; Jacobson and Birks, 1980).

John's research was supported by Sylvia Peglar, who was the technician in charge of the pollen lab of the Botany School. With John's guidance, she substantially upgraded and extended the reference collection incorporating a wider range of taxa, typically from field collections rather than herbaria, and changing from glycerinemounted slides to silicone oil. She prepared and counted John's pollen samples, and finalised his diagrams by hand on a draftsman's drawing board. Much later, after she moved with him to Bergen, she undertook a PhD thesis on cores from Diss Mere (Peglar, 1992), supervised by John, so she was in a sense the last of his Cambridge PhD students, although she worked with him from 1972, longer than anyone except Hilary, his wife since 1966. John had 11 other Cambridge PhD students: Leslie Rymer (1974), Peter Beales (1976), Colin Prentice (1976), Paul Adam (1976; although not Paul's designated supervisor, John was his principal advisor), Brian Huntley (1976), Will Williams (1976), Richard Bradshaw (1978), Mary Edwards (1980), Henry Lamb (1982), Keith Bennett (1982) and Paul Kerslake (1982). Most of his doctoral students had been Cambridge undergraduates, the exceptions being Mary Edwards (Aberystwyth and Oxford) and Henry Lamb (Dublin and Minnesota). Their research topics were largely on vegetation history and phytosociology in NW England, Scotland, Wales and East Anglia, although Henry Lamb continued to work on Labrador palaeoecology, doing fieldwork with Herb Wright. Seven of them have now become respected senior academics and one a government conservationist. Researchers visited the Cambridge group from Canada, Finland and the United States (including Tom Webb, Tom
Shay, Rolf Mathewes, Matti Saarnisto, Herb Wright and Eric Grimm), and together with postdoc Brian Huntley, they further invigorated the pollen group. As a colleague, John was readily accessible in his small but immaculate top-floor office, with its meticulously organised reprint collection that he made available to all. He actively advised and encouraged his $\mathrm{PhD}$ students, especially in computing and numerical methods, but gave them free rein to develop their own projects. He was generous in allowing students to publish on their own, which perhaps explains the relatively few joint publications from this period. Those were the days when diagrams for publication still required painstaking drafting by hand, although computing was gradually taking hold. Voluminous decks of punched cards were needed for data input to John's Polldata, zonation and PCA programs and the vegetation classification program TWINSPAN, run on the Cambridge mainframe located on the other side of Downing Street and accessed via the notorious 'blue staircase'. Error correction involved much physical as well as mental exercise! John continued his interest in modern vegetation and ecology, and was a leader of the British National Vegetation Classification (Rodwell, 1991-2000).

John's strong interest in early music began in Cambridge through his association with Christopher Hogwood, then Director of the Academy of Ancient Music, and with Nick Shackleton in the Godwin Lab. John initiated the first chamber concerts in Sidney Sussex College chapel, and certainly helped spark a similar interest in several of his students. He also held informal discussion group meetings in his Sidney rooms, meetings that involved staff, postdocs and students from several Cambridge departments and focused on ecological or biogeographical issues rather than the more geological themes that dominated proceedings in the widely known Quaternary Discussion Group, run by Richard West, Nick Shackleton and Philip Gibbard.

Fieldwork with John was intensive, well planned and well organised. He was assiduous in contacting landowners, including on one occasion (in East Anglia with Keith Bennett) mollifying an irate landowner, when access permission from the tenant proved to be inadequate. In North Wales, Mary Edwards, Peter Coxon and Henry Lamb struggled to get John down to the bar of the local hotel as, dedicated to science as always, he had a tendency to stay in his room writing up field notes, unless encouraged otherwise. On other occasions, John was observed to sit up late into the night in his tent, reading papers by torchlight.

John's years in Cambridge were full and productive across a wide range of subjects and set the foundation for the extraordinary productivity of his subsequent work in Bergen. He and Hilary made important contributions to the vegetation history of Scotland in particular (Birks and Madsen, 1979; Birks and Peglar, 1979; Birks, 1996), including a preliminary synthesis (Birks, 1977b), an impressive excursion guide (Birks, 1980b) and an important regional synthesis (Birks, 1996). His most significant and lasting achievement up to 1984 was, in collaboration with John Line, to introduce numerical methods into pollen analysis, culminating in Numerical Methods in Quaternary Pollen Analysis, co-authored with Allan Gordon (Birks and Gordon, 1985), his graduate student contemporary. His bibliography shows 5 books and 93 papers for the Cambridge period, of which the most cited all include multivariate statistical methods. A measure of his achievement is undoubtedly his role in fostering an academic environment that stimulated his students to continue their careers in ecology, biogeography, palaeoecology, palaeoclimatology, palaeolimnology and nature conservation.

\section{The Bergen years}

John Birks moved to Bergen from Cambridge in 1984 as a visiting researcher. He joined the ecological and palaeoecological research group in the Botanical Institute, now referred to as the 
Former Botanical Institute (FBI) following the merger of four institutes into the Department of Biology in 2004. In 1985, his position in Bergen was made permanent and he became a full professor in 1987. His plan was to continue pollen analysis and study long-term vegetation change in Norway as well as to further develop quantitative methods (Birks, 2014). However, his plans changed as he became involved in the 'acid-rain' debate, joining the Surface Water Acidification Project (SWAP) in 1986, a major international project involving scientists from Norway, Sweden and the United Kingdom, designed to resolve the causes of surface water acidification once and for all (see also below).

Together with the Dutch statistician Cajo ter Braak and Steve Juggins, a UCL post-doctoral researcher at the time, he developed novel numerical methods to revolutionise the use of diatoms as predictors of $\mathrm{pH}$ based on a training set of diatom assemblages from the surface sediments of lakes across Norway, Sweden and the United Kingdom (Birks et al., 1990b). With John Line, he subsequently published a very influential and popular computer program, WACALIB, to implement the reconstruction of environmental variables from fossil assemblages by weighted averaging (WA; Line and Birks, 1990).

Along with other proxies, diatom analysis and the diatom- $\mathrm{pH}$, transfer function approach was applied to a number of remote mountain-top lakes in Norway to test the hypothesis that land-use change rather than acid deposition was the principal cause of acidification. As expected, the study showed that the lakes had indeed been recently acidified and the land-use hypothesis was refuted (Birks et al., 1990a). The introduction of numerical analytical methods helped to transform the young science of palaeolimnology and the transfer function approach has been widely used on numerous proxies throughout the world.

SWAP was the first of many large multi-proxy and multi-disciplinary projects that have been conducted in Bergen under John's leadership, most with a focus on climate and vegetation change since the last ice age. Norway presented John with a new country with mountains and their plants to explore. The ecological understanding gained by these explorations formed the basis of these projects. They included: (1) KILO (Kiruna to LOfoten) with lake Bjørnfjelltjørn near Narvik as one of the main sites (Bjune et al., 2010); (2) the southern Norway Setesdal-project where modern pollen as well as modern and fossil sediment samples were analysed in great detail (e.g. Eide et al., 2006; Felde et al., 2014); (3) the Oslo To Trondheim transect or, as it was also called, the 'over-the-top' (OTT) project; (4) environmental reconstructions on Svalbard during the last two millennia (with colleagues at UCL; Birks et al., 2004b); (5) reconstructions of past climate and environments in NORPAST-1 and -2 (Past Climates of the Norwegian Region; Birks and Birks, 2006; Nesje et al., 2006; Bjune and Birks, 2008); (6) the large Strategic University Programme NORPEC (Norwegian palaeoenvironments and climates as reconstructed from lake sediments; e.g. Velle et al., 2005; Bjune et al., 2005; Heggen et al., 2012); and (7) the NoAClim (No-analogue climates and ecological responses in the past and future) project.

Many researchers and students have been involved in these projects, many lakes have been cored and hundreds of kilograms of lake mud have been analysed. All projects used a multi-proxy approach, including pollen, plant macrofossil, chironomid, diatom, oribatid mite and sediment analyses, and data were analysed using innovative numerical methods. The use of transfer functions for reconstructing climatic variables from different biological proxies found in lake sediments has been a central theme. Many of the ideas and methods in the early projects were important for the initiation, establishment and development of the Bjerknes Centre for Climate Research in Bergen in 2000, where John played a leading role encouraging palaeoclimatologists to work together with palaeoecologists, modellers, oceanographers and meteorologists in a multi-disciplinary manner.

John's extremely productive career has been widely recognised. In 1987, he was elected a Foreign Member of the Norwegian Academy of Science and Letters, and in 1998, he was presented with the Fridtjof Nansen award for excellent research. He was also elected to an honorary doctorate at Lund University in 1998 and became an Honorary Fellow of University College London in 2010. In 2012, he received a Lifetime Achievement Award from the International Paleolimnology Association (see above). On 10 August 2007, John was ranked the sixth most cited geoscientist world-wide for 1996-2007 by Thompson's Web of Science.

To encourage and stimulate researchers and students in Bergen to use statistical techniques, John created the lunchtime seminar group Quantitative Ecology and Palaeoecology Research Group (QEPRG, nicknamed Queens Park Rangers) which later became the Ecological and Environmental Change Research Group (EECRG). In both groups, the aim was to bring together researchers and students working on past, present and future ecosystem change to understand the natural variability of ecosystems as well as the effects of human impact. A central aim was to encourage students to present their work in English, and thus become international scientists (Birks, 2004). The tradition of training, teaching, discussion and exchange of knowledge was fundamental to the conduct of research projects and to the culture of research in the Bjerknes Centre.

Teaching has played an important role in John's academic life. He has taught many courses on plant ecology, palaeoecology, pollen analysis and numerical methods during his years at the Universities of Cambridge and Bergen, and through his lectures, he has inspired many young scientists. His outreach has included many talks and presentations at international and national meetings, as well as more relaxed summer schools and short courses around the world. Of especial note is the Bern bog excursion (Moorexursion) that he has organised and led three times, every 10th year since 1992! The excursions followed the trails of John's research, first to the Isle of Skye, then to western Norway and, in 2012, around eastern and southern Norway.

Many of us have been lucky to join in John's fieldwork campaigns. Researchers, students and technicians from many countries and institutions in addition to the Bergen group have often been squeezed into a van for a week or two together with field equipment, core boxes, rubber boots, maps and a good CD collection! The number of lake sediment cores and surface samples that have been collected on these trips is enormous and probably all have been analysed at least for one proxy, becoming the basis for many $\mathrm{MSc}$ and $\mathrm{PhD}$ theses.

Since John came to Bergen in 1984, he has supervised 27 MSc (and Cand. Scient.) students and $21 \mathrm{PhD}$ students (Figure 4). In addition, 23 Marie Curie fellows and numerous other scientists from almost all corners of the world have visited, covering many aspects of ecology and palaeoecology. There have been many highlights both for John and for the group, one of which must be La Duo, who in 2008 was the first Tibetan ever to be awarded a $\mathrm{PhD}$ in biology! Funding successes, especially in the 1990s and early 2000s, allowed the group to grow and enabled travel to meetings, workshops, seminars and excursions and the building of research networks around the world, that continue to flourish today.

It is quite clear that neither the EECRG as a group or its individual members would have been so successful if it had not been for John and his commitment to scientific excellence! We are all grateful to John for his leadership, friendship, supervision and eternal support! 


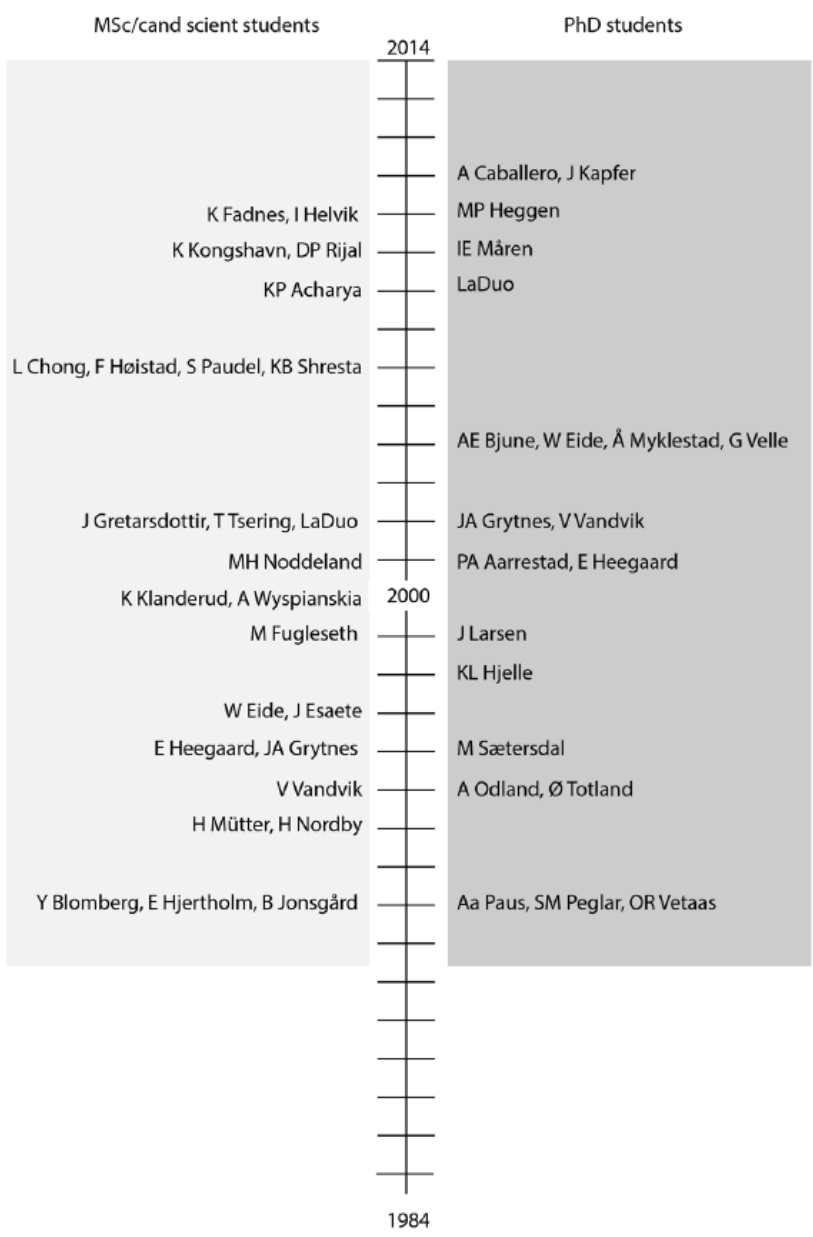

Figure 4. MSc/cand scient (red) and $\mathrm{PhD}$ students (blue) supervised by John Birks in Bergen with date of thesis defence (Prepared by Anne Bjune).

\section{Lund and Abisko}

When visiting the Botany School during a symposium in Cambridge in the spring of 1969, Björn Berglund met John and Hilary Birks for the first time. In the summer the same year, they came to Lund and an excursion was arranged to the Blekinge coast and archipelago in southeastern Sweden. Since that time, John and Björn have had continuous contact that has stimulated the research of several generations of research students at the Department of Quaternary Geology, Lund University. John returned to Lund as a visiting lecturer several times, particularly during the 1970s and 1980 s, teaching the importance of numerical techniques in palaeoecology with a focus on Holocene vegetation history. He gave a more substantial course in Lund in 1977 which resulted in a joint paper (Birks and Berglund, 1979). With John's interest in mountain vegetation, it was natural to invite him to the Nordic summer courses at Abisko in Swedish Lapland, where he was a stimulating teacher and field guide in 1978 and 1988.

In 1985, John designed a Scandinavian research programme for palaeofloristic mapping based on pollen data. This was later included in a European project. And during the period 1984-1992, he acted as a research consultant for The International Geological Correlation Programme: 'Palaeohydrological changes in the temperate zone during the last 15,000 years' which deepened collaboration with Lund as well as stimulated research exchanges between palynologists all over Europe. John subsequently played an important role in the production of the Handbook of Palaeoecological Methods that was published as a result of this project (Berglund, 1986), where he wrote a very influential overview

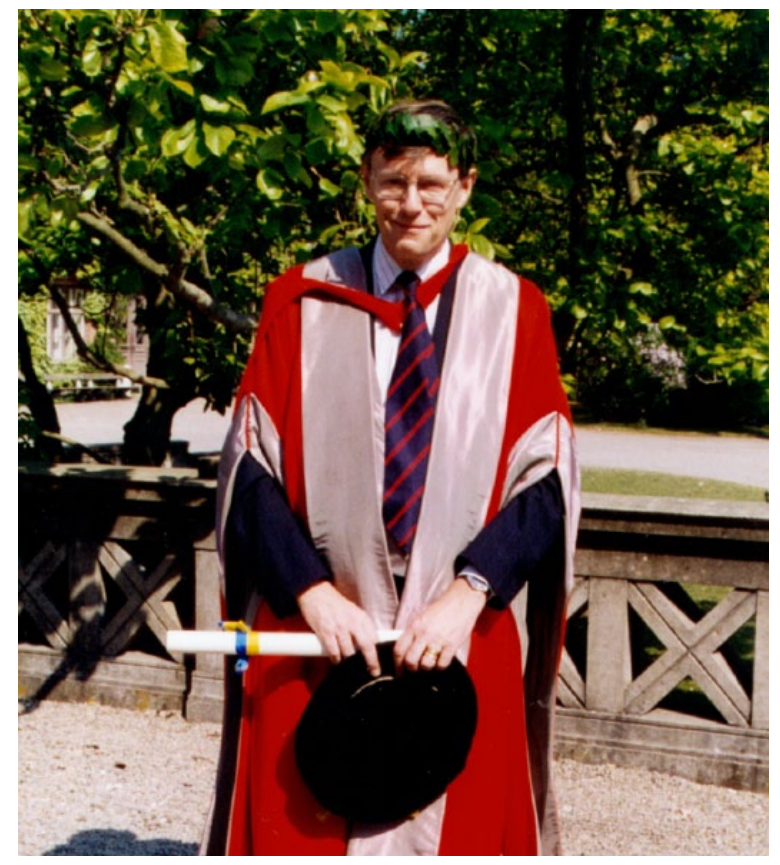

Figure 5. John Birks, Lund 1998, Philosophiae Doctor Honoris Causa.

Source: Photo by Hilary H Birks.

chapter on Late-Quaternary biotic changes (Birks, 1986). This handbook was later followed by a monograph of European pollen data (Berglund et al., 1996). In recognition of his major contribution to the methodological development of pollen analysis and for his scientific collaboration with Lund University, in 1998, he was honoured as Philosophiae Doctor Honoris Causa at Lund University (Figure 5). In 2013, together with Hilary Birks, he was invited to present the Tage Nilsson Memorial Lecture in Lund (Tage Nilsson was the founder of Quaternary Palynology in Lund).

\section{The UCL connection}

Although John Birks and Rick Battarbee first met in Cambridge in 1972, it was not until 1986 that an opportunity of working together arose. By chance John was attending a seminar Rick gave to Björn Berglund's group in Lund about the work that Roger Flower and he were doing on the acidification of lakes in Scotland. John asked no questions in the seminar but afterwards very politely told Rick that he had reservations about the method of reconstructing $\mathrm{pH}$ from diatoms that Roger, he and others were using (e.g. Flower and Battarbee, 1983; Renberg and Hellberg, 1982), and asked whether he could help. He had previously given the matter some thought and had realised that Cajo ter Braak's innovative approach to species-environment modelling using canonical correspondence analysis (e.g. ter Braak, 1986) was perfectly suited to solving the problem of diatom-pH calibration. In a following exchange of letters with Rick, John also outlined how he thought the new techniques of statistical re-sampling including bootstrapping and jack-knifing might be used to ascribe standard errors for diatom $\mathrm{pH}$ reconstructions, an issue that the UCL group had been taken to task over by acid-rain sceptics from the UK power generating industry. As John, at the request of Knut Fægri, had earlier that year joined the SWAP (Battarbee and Renberg, 1990) and as Steve Juggins in UCL had already been exploring ter Braak's statistical techniques in his $\mathrm{PhD}$ on diatom-salinity relationships on the River Thames (Juggins, 1992), Rick invited John to London to run a workshop on numerical methods. His intention 
was to bring members of the wider Environmental Change Research Centre (ECRC) group in UCL up to speed on the use of multivariate statistical methods in palaeoecology and to explore how to combine forces in developing a new approach to diatom$\mathrm{pH}$ reconstruction that could be applied across all the SWAP sites in Norway, Sweden and the United Kingdom.

The workshop, in early March 1987, was significant in a number of ways. It was the start of a dedicated research programme on diatom-pH transfer functions that culminated in the publication of the now classic paper in Philosophical Transactions of the Royal Society on 'Diatoms and pH' (Birks et al., 1990b). It was the beginning of a long-standing and very productive research collaboration which continues to this day with John and many members of the ECRC on a range of palaeolimnological projects, and it was the forerunner of the annual UCL short course on 'Numerical Methods of Biological and Environmental Data Analysis' that flourished for over 25 years assisted in the first instance by Steve Juggins, followed by Martin Kernan and then by Gavin Simpson, who ultimately took over running the course.

Collaboration was further facilitated when UCL invited John to become the 'ENSIS Professor of Quantitative Palaeoecology' at UCL in 1993. This $20 \%$ appointment enabled John to join the academic staff of UCL, to take part in the ECRC's research programme and to teach Masters students in Quaternary Science, most notably running a course in Pollen Analysis with Sylvia Peglar. During those years, John was a very frequent visitor, being fully involved with the work of the ECRC. After SWAP, he worked together with Rick Battarbee, Neil Rose, Nigel Cameron and others on mountain lakes in the EU projects Alpine Lake: Palaeolimnology and Ecology (AL:PE) and Mountain Lake Research (MOLAR; Battarbee et al., 2002b). These projects provided an opportunity to extend the diatom-pH training sets including not only one for alpine lakes calibrated using surface sediments but also one using epilithic diatoms which yielded one of the highest RMSEP of any training set published (Cameron et al., 1999). The MOLAR project involved a comparison between proxy data from the recent sediments of a range of European mountain lakes and instrumental climate data for each site. John and his Bergen colleagues, John-Arvid Grytnes and Einar Heegaard, played a central role in the data analysis especially in the novel use of LOESS regression (Cleveland et al., 1993) to smooth the instrumental data to enable statistical comparisons with the palaeo-data for different timespans (Battarbee et al., 2002a).

Interest in remote regions extended to both Antarctica and the Arctic. In Antarctica, building on the previous work of Viv Jones on lakes on Signy Island, South Orkneys, John worked with Philippa Noon to develop a model for reconstructing catchmentice extent (Noon et al., 2001). In the Arctic, John collaborated with Neil Rose and Viv Jones in a multi-disciplinary project on Svalbard lakes designed to assess palaeolimnological evidence for recent environmental change, a project which led to a special issue of Journal of Paleolimnology (Birks et al., 2004a) with John contributing to six of the papers, including those on modern limnology and vegetation (Birks et al., 2004c), diatoms (Jones and Birks, 2004), chironomids (Brooks and Birks, 2004) and sediment geochemistry (Boyle et al., 2004). The synthesis paper (Birks et al., 2004b) included a novel approach to quantify estimates of the rate of compositional change in diatom and chironomid data as a means of comparing sites and proxies.

Further collaboration with members of the ECRC included work with Emily Bradshaw on the diatom analysis of sediments from Kråkenes (Bradshaw et al., 2000), Roger Flower on North African lakes (the EU-CASSARINA project; Birks et al., 2001), Catherine Dalton on the EU-Project CHILL-10,000 (Dalton et al., 2005), Nadia Solovieva on palaeolimnological evidence for climate warming in the northern Urals of Russia (Solovieva et al., 2005), Giri Kattel in Scotland on a Cladocera-temperature transfer function (Kattel et al., 2008), Virginia Panizzo on the analysis of early Holocene sediments of a Norwegian lake (Panizzo et al., 2008), Angela Self on the development of a new chironomid-temperature inference model for northern Russia (Self et al., 2011) and Viv Jones on the diatom analysis of sites in John's NORPEC project (see above; Birks et al., 2012a).

A continuing feature of John's relationship with the ECRC has been the help and encouragement he has given to ECRC statisticians, first Steve Juggins, in the early years, and more latterly Gavin Simpson. Under John's leadership, these three have pioneered a number of the techniques and numerical tools now routinely used in palaeolimnology, as described in the masterly DPER volume on 'Tracking Environmental Change using Lake Sediment: Data Handling and Numerical techniques' that John edited and that contains a number of chapters that he either authored or co-authored (Birks et al., 2012b).

On his retirement from UCL in 2010, John's major contribution to the College was recognised by the award of a prestigious Honorary Fellowship and an appointment as an Emeritus Professor. UCL students and colleagues continue to benefit from his advice and strive to follow his basic principle that, according to Rick Battarbee's lecture notes from that first numerical workshop in 1987, numerical techniques should be not only 'computationally possible' but also 'ecologically sensible'.

\section{Queen's University, Kingston}

John Birks has had a long and fruitful relationship with the Paleoecological Environmental Assessment and Research Lab (PEARL), at Queen's University in Kingston (Canada), where he has held a long-term adjunct professorship and has worked closely with Brian Cumming and John Smol, and their many students and post-doctoral fellows. His many contributions with PEARL scientists can be divided into three major areas.

First, the PEARL lab was heavily involved in North American acidification issues where Smol with then graduate student Brian Cumming were working as part of the Paleolimnological Investigations of Recent Lake Acidification (PIRLA) project on developing and applying palaeolimnological methods to track lake acidification in Adirondack Park (New York, USA). John played a key collaborative role in developing transfer functions for chrysophytes (Cumming et al., 1992a) and diatoms (Dixit et al., 1993), and then applying these functions to answer questions such as 'have Adirondack lakes acidified (Cumming et al., 1992b), and, if so, when?' (Cumming et al., 1994). By incorporating invertebrate indicators, questions related to past trends in acidsensitive fish stocks were also addressed (Kingston et al., 1992). Brian Cumming also had the opportunity to spend a term at Bergen with John, where comparable chrysophyte data were analysed for Norwegian lakes (Cumming et al., 1991).

The second major topic of collaboration with the PEARL group was in the area of climate change. For example, working with post-doctoral fellow Ian Walker and $\mathrm{PhD}$ student Reinhard Pienitz, the first chironomid-based transfer function was published (Walker et al., 1991) as was some of earliest quantitative work dealing with diatoms and climate change (Pienitz et al., 1995). John's numerical expertise was crucial in subsequent studies, such as a meta-analysis of a large number of palaeolimnological studies showing that climate was the main driver of palaeolimnological proxies in the recent sediments of circumpolar Arctic lakes (Smol et al., 2005).

Finally, John has played a key role in synthesising the various methodologies used in palaeolimnology by editing a series of volumes in the Developments in Paleoenvironmental Research book series (Smol et al., 2001a, 2001b), including his strong leadership in the recent volume on numerical methods (Birks et al., 2012b), as described above. 


\section{The Bern and Utrecht connections}

It was in 1985 during a combined excursion of the Quaternary Botanists and the IGCP 158B project through Switzerland that Brigitta Ammann, then post-doctoral fellow in Gerhard Lang's Bern Geobotany group, approached John Birks at an enforced long customs stop at the Swiss-Italian border on the Simplon pass (thus preventing him from taking pictures of Saxifraga cotyledon) about the possibilities of examining her multi-proxy data from Lobsigensee using a numerical approach. John thought about it but unfortunately this project never took off. However, in 1988, John was invited to Bern to give an introductory course on multivariate data analysis, and this was the beginning of a long and fruitful collaboration. First, questions on the late-glacial vegetation development (Lotter et al., 1992; Ammann et al., 1993) were tackled, then the focus changed to the reaction of terrestrial and aquatic ecosystems in relation to late-glacial climate change and volcanic eruptions (Lotter and Birks, 1993; Birks and Lotter, 1994; Lotter et al., 1995) and to disentangling the effects of climate change and nutrient enrichment on the formation of annually laminated sediments (Lotter and Birks, 1997). John helped to construct empirical response models (transfer functions) for several aquatic organism groups in Central Europe and the Alps in relation to temperature and nutrients (Heiri et al., 2011; Lotter et al., 1997, 1998) and was strongly involved in the analysis of Brigitta Ammann's multi-proxy late-glacial data from several sites in the Alps (Ammann et al., 2000; Lotter et al., 2000). After Andy Lotter's appointment in Utrecht, The Netherlands, cooperation continued with multi-proxy projects in the Alps investigating catchment-lake interactions during the Holocene across the tree line (Lotter and Birks, 2003a, 2003b) as well as the location of ecotonal situations for aquatic organisms (Heegaard et al., 2006). In 2012, more than 20 years of this collaboration culminated in the publication of the Data Handling and Numerical Techniques book (Birks et al., 2012b).

\section{The Helsinki connection}

The early 1990s was a time of rapid expansion in the fields of quantitative palaeolimnology and palaeoecology in Finland. A particular stimulus was provided by the research project ' $\mathrm{Cli}$ mate History as Recorded by Ecologically Sensitive Arctic and Alpine Lakes in Norden (Nord-CHILL)', funded by the Nordic Council of Ministers in 1995-1996 and the following EU framework project 'Climate History as Recorded by Ecologically Sensitive Arctic and Alpine Lakes in Europe (CHILL-10,000)' in 1997-1999. The main objective of these projects was to construct transfer functions for diatoms, chironomids, cladocera and pollen. Atte Korhola coordinated the projects and John Birks was responsible for the use of the quantitative methods in them. As part of this collaboration, John Birks and Heikki Seppä started to work together on a new pollen-based calibration model for Fennoscandia. Recognising the many weaknesses of the continentalscale modern and fossil pollen datasets that were available at the time, strict criteria for inclusion of data in this new Fennoscandian pollen-climate dataset were set. The modern pollen samples were collected only from the central parts of small to medium size lakes, to ensure that the samples represented the regional rather than local vegetation, and care was taken to harmonise all stages of pollen sampling, sample preparation, pollen identification and taxonomy.

The Fennoscandian pollen-climate calibration model was ready for palaeoclimatic use by 1999 , and the first joint paper was published in 2001 (Seppä and Birks, 2001). This paper included both the presentation of the new calibration model which comprised 164 modern pollen samples from Norway, 113 from
Finland and 27 from northern Sweden, and Holocene July mean temperature and mean annual precipitation reconstructions from a new high-resolution pollen record from Lake Toskaljavri in northwestern Finnish Lapland. A further reconstruction with comparable temporal resolution was published the next year from another subarctic lake in Finland, and one of the main results of this pair of records was that the general trends in pollen-based Holocene climate reconstructions appeared to be consistent, but the higher frequency patterns did not match (Seppä and Birks, 2002).

During the 1990s, many key papers were published describing and analysing modern calibration training sets that did not include fossil data or environmental reconstructions. Some of these studies caused a lively debate about organism-environment relationships in arctic regions (Olander et al., 1999; Korhola et al., 2001). A need for a similar modern calibration model paper for pollen data was recognised and such a paper was consequently published by Seppä et al. (2004). One of the main ideas in the paper was to select modern pollen samples so that they formed a relatively simple south-to-north transect from Estonia to Finland, along a gradient of decreasing temperature. The Fennoscandian pollen-climate calibration dataset was then rapidly expanded in the early 2000 s to include more modern pollen samples from Sweden, from the Baltic countries and, since 2006, increasingly from European Russia.

Many palaeoclimate papers have been published using this calibration model. Most have focused on the Holocene, but an interesting experiment was carried out with fossil pollen data from the interstadial site Sokli in northern Finland. The pollen data were analysed by Karin Helmens and the subsequent paper, published by Helmens et al. (2007), described the difficulties that often emerge in a multi-proxy study when the calibration models based on modern samples are applied to potentially non-analogous fossil data from, for example, a Pleistocene interstadial or interglacial. Among the Holocene studies, one of the most important (Seppä et al., 2009) included pollen-based July mean temperature and annual mean temperature reconstructions produced from 36 sites in northern Europe combined to create 'stacked' July mean temperature and annual mean temperature curves. These 36 records and many other quantitative climate reconstructions based on various biological proxies were eventually included in the Arctic Holocene Database collected and published by Sundqvist et al. (2014). Fennoscandia stands out in this dataset as the region with highest density of records in the whole arctic region - testimony to the unrivalled contributions of John Birks in quantitative palaeolimnology and palaeoecology in Fennoscandia.

\section{The Oxford connection}

John first met Kathy Willis in 1992 at the Palynological Congress in Aix-en-Provence. However, it wasn't until 15 years later that John and Kathy worked together in the same department, office and College when John joined Kathy and her Oxford Long-term Ecology laboratory (OxLEL) for a two-term sabbatical visit as a Visiting Senior Research Fellow at Jesus College, Oxford. John's time in Oxford was divided into four distinctive activities: reading and writing in a tower-room above the main Quad in Jesus College; collaborating, advising and interacting with students and postdocs in the laboratory; total immersion in all aspects of collegiate life including regular dining at High Table; and going to as many classical concerts as any one person could possibly attend in 6 months. As always, John pursued all of these activities with enthusiasm, vigour and meticulous planning. His position in the tower-room also gave him the ideal vantage point to view all comings and goings in the College through the main archway and many a time he would undertake a complex 'sign-language' conversation with people in the Quad below to signal a coffee/lunch/tea break. 
John's input to numerous projects and papers that were being undertaken at the time of his visit was invaluable - but his time in Oxford represents a tiny fraction of the discussions, ideas and sometimes papers that have emerged from his interactions with members of OxLEL over the past 15 years. These can be broadly categorised into research that addresses three challenging questions: first, 'what is natural?' that is, the use of palaeoecological records to determine critical baselines for all aspects of natural resource stewardship and biodiversity conservation (Willis and Birks, 2006; Bhagwat et al., 2008; Willis et al., 2010a). Second, the question 'which plant species/populations/communities are most resilient to environmental perturbations over time and what types of environment have provided important refuges to enable persistence?' Papers published on this topic include those looking at vegetation responses to climate change (e.g. Willis et al., 2010b) and the location and role of refugia in Europe during the last fullglacial to provide persistence of a number of temperate tree taxa (e.g. Birks and Willis, 2008). Third is a question where work is still ongoing and that is 'to what extent have major ecological and evolutionary changes (as apparent in plant fossil records) been driven by variations in incoming UV-B flux?' The original discussions and ideas for this paper came about while John was in Oxford (Willis et al., 2009), but since then, work has been ongoing to develop a new methodology for determining variations in UV-B flux in the aromatic compounds contained in fossil Pinus sylvestris pollen (Willis et al., 2011) and developing the first continuous UV-B records from late-glacial to present from fossil records in Norway, Scotland and the United Kingdom to enable comparison of rates of plant community turnover with UV-B flux.

\section{The Potsdam connection}

In collaboration with John Birks, Ulrike Herzschuh, who had visited Bergen in 2004 as an EU Marie Curie Fellow, introduced quantitative climate and vegetation reconstruction methods to Tibetan palaeo-vegetation science. They built a modern pollen training set solely based on lake sediments and used it to explore pollen-climate and pollen-vegetation relationships for the Tibetan Plateau (Herzschuh and Birks, 2010; Herzschuh et al., 2010a). The training set was then used to derive transfer functions that were applied to a number of post-glacial pollen records from Tibetan lakes (Herzschuh et al., 2010b; Wang et al., 2013).

Ulrike Herzschuh especially valued John Birks' guidance in hypothesis-driven research that included his strict advice to choose the most parsimonious explanation when exploring complex phenomena. This research principle was applied when together they explored the combined effects of early Holocene low atmospheric $\mathrm{CO}_{2}$ concentration and high-altitude on Tibetan plant composition (Herzschuh et al., 2011) and when they investigated the interactions among larch forests, thaw-lake ion chemistry and permafrost on millennial and centennial time-scales in Siberia (Herzschuh et al., 2013).

\section{The special issue papers}

The following papers in this special issue span a wide range of topics representing John's diverse scientific career (Birks, 2014). They are divided into a number of themes including ecology and palaeoecology, late-glacial and Holocene palaeoecology, ecological succession, numerical methods, climate history and the impact of people on terrestrial and aquatic ecosystems.

\section{Ecology and palaeoecology}

The first paper in the issue (Bjune et al., 2015) is by John Birks' colleagues in the University of Bergen. It deals with John's dual interests in ecology and palaeoecology and, from a study of the papers published by John's former students, explores how and why the division between these closely related subjects appears to be widening. The authors suggest the growing division is a reflection of increasing research specialisation and that the different communities could interact more if titles, keywords and abstracts in published papers were better designed to reach a wider audience.

\section{Late-glacial and Holocene palaeoecology}

Throughout his career John, together with his colleagues and students, has been at the forefront of studies using a multi-proxy approach to the reconstruction of late-glacial and Holocene environments. Several papers in this issue are concerned with this theme.

Seddon et al. (2015) explore the importance of climate change as a principal cause of vegetation change in Northern Europe. Using data from the European Pollen Database, they identified two time intervals (the Younger Dryas-early Holocene transition (c. 11.6-9.0 kyr BP) and the early-middle Holocene (9.0-6.0 kyr BP)) as periods of high pollen assemblage turnover. Whereas the late-glacial-early Holocene pollen changes were regionally coherent and strongly related to temperature change, the Holocene changes were highly variable and site specific, suggesting that the Holocene changes were mediated by local influences. They argue that the data highlight the importance of understanding the relationship between local threshold dynamics as well as external forcing in explaining vegetation change during this period.

In the next paper, Hilary Birks (2015) poses the questions whether the north-south vegetation and climate gradients that exist today in Norway were similar in the late-glacial and early Holocene time periods. From a comparison between the plant macrofossil records and chironomid-inferred July temperatures from three sites at different latitudes, Birks argues that the temperature gradient during the Allerød was similar to that at present, albeit $3-4^{\circ} \mathrm{C}$ cooler. In contrast, the differences between the sites were not so pronounced during the Younger Dryas probably because of the influence of a glacier and longer lasting snowbeds in the catchment of the most southerly located site (Kråkenes) than further north where the climate was more arid and continental. In the early Holocene, temperature and oceanicity increased northwards as the North Atlantic Current became established with birch woodland developing 1450 years after the start of the Holocene in the far north compared with 650 years in the south.

Seppä et al. (2015) assess the use of palaeoecological data in mapping past plant distributions. They compare the Holocene range shift of hazel (Corylus avellana) in Northern Europe, based on the fossil record of hazel nuts, with its distribution at the Holocene Thermal Maximum (HTM) as simulated by the dynamic vegetation model LJP-GUESS. Despite some differences, the fossil data and modelled data are largely congruent, indicating that hazel did indeed reach its climatic limits (at c. $63-64^{\circ} \mathrm{N}$ ) during the HTM when mean annual temperature was approximately $2.5^{\circ} \mathrm{C}$ warmer than present. The authors argue that the projected future warming of about $2.5^{\circ} \mathrm{C}$ would reverse the long-term late Holocene southward reduction of the species' northern range limit in Europe and potentially lead to the migration of hazel as a common, regeneratively reproductive species back to its Holocene maximum.

In contrast to the hazel expansion in Northern Europe, Franklin-Smith et al. (2015) present evidence for the mid-Holocene range expansion of a tree species not related to climate change. The authors use pollen and fossil stomata evidence from four sites to track the spread of lodgepole pine (Pinus contorta) in the Yukon Territory of Canada. They argue that lodgepole pine was only a minor component of the extant spruce forest in the early to midHolocene and that populations were prevented from expanding 
because of biological constraints on reproductive success rather than to limitations imposed by climatic conditions. However, using evidence from the charcoal record at the different sites, they suggest that the expansion of local populations was facilitated by a regime of frequent fires and that any increase in fire frequency in future, related to anthropogenic activity or climate change, could lead to further population expansion.

In the paper of Cao et al. (2015), the spatial and temporal distributions of 14 key arboreal taxa and their driving forces during the last $22 \mathrm{cal} . \mathrm{kyr}$ in the eastern part of continental Asia were explored using a harmonised fossil pollen dataset. The thermophilous and eurythermal broadleaved tree taxa were shown to be restricted to the current tropical or subtropical areas of China during the Last Glacial Maximum and spread northward after $c .14 .5$ kyr BP. Betula and conifer taxa, in contrast, retained a wider distribution during the LGM and showed no distinct expansion direction during the late-glacial. Since the late mid-Holocene, the abundance but not the spatial extent of most trees decreased. Results indicated that the changes in spatial and temporal distributions of these tree taxa are a reflection of climate change in particular of monsoonal moisture. However, in the late Holocene, human activity influenced the relative abundance of single tree taxa but not the extent of their range.

Hargan et al. (2015) use macrofossil, algae, testate amoebae and pollen analysis to reconstruct the climatic and environmental history of the Hudson Bay Lowlands of central Canada, a region that contains one of Earth's largest continuous peatland complexes. They argue that from c. 2000 to 600 years ago, changes in diatom composition from three peat cores reflect hydroseral succession within the peatland including fluctuations in connectivity to the water table and associated $\mathrm{pH}$ changes. However, from $c$. 600 years ago to the present day, they suggest that the diatom and testate amoebae records track drying conditions and related subtle changes in the morphology of the peatland surface. Each proxy in the study represents a distinct position within the peatland ecosystem. The authors maintain that multi-proxy approaches can be complex, but they strengthen understanding of past environmental change.

\section{Ecological succession}

In tribute to John Birks' research on plant succession and vegetation history on glacier forelands, most notably at the Klutlan Glacier, Yukon Territory, Canada (Birks, 1980a, 1980c), Vater and Matthews (2015) present data on invertebrate succession on glacier forelands in Norway. They use chronosequences to compare invertebrate taxa within and between glacier forelands of different altitude. For each foreland, they use pitfall traps to collect insects and arachnids along transects at increasing distance away from the glacier snout comparing sites that have been exposed for less than 20 years to sites exposed for more than 250 years. They show that in the alpine zone, there is a relatively simple two-stage succession from a pioneer stage to the mature stage, whereas at lower altitudes, in sub-alpine and boreal zones, the succession is more complex with later colonisers being relatively more important and where succession is influenced by local exposure and moisture differences. The authors argue that the results support the 'addition and persistence' model of succession whereby the succession is driven primarily by the individualistic behaviour of highly mobile (mainly carnivorous) species exhibiting low dependence on the vegetation succession.

\section{Numerical methods}

One of John Birks' major contributions to palaeoecology has been the development and application of numerical methods for data analysis, especially in the field of palaeolimnology where his pioneering work on transfer functions and their use in environmental reconstruction and prediction has been adopted globally. Here, Juggins et al. (2015) discuss whether transfer functions can be improved by removing taxa that are not related to the environmental variable being reconstructed from training sets. Using a random forests approach, they develop a novel species-pruning algorithm to identify non-informative taxa as a means of creating a training set with an optimal number of taxa and a predictive model with the smallest error. Using both artificial and real datasets, they then apply the algorithm to WA and maximum-likelihood (MLRC) transfer function approaches, and compare the results with those from boosted regression trees (BRTs). The results from the artificial data show that WA is particularly sensitive to the influence of both non-informative taxa and secondary environmental variables and that BRTs and species-pruned WA and MLRC models are relatively immune to these effects. However, tests with a limited set of examples of real data indicate that BRTs, MLRC or species-pruned models have no apparent advantage over WA. They discuss possible reasons for the contradiction and highlight the need for further testing.

\section{Climate history}

In the $1990 \mathrm{~s}$, as climate change became the most pressing environmental issue of the day, palaeoecologists turned their attention to the potential of reconstructing climate history from lake sediment records. John Birks became especially interested in the use of chironomid head-capsule records as a means of reconstructing July temperatures through the Holocene in Norway (e.g. Brooks and Birks, 2001). Here, three papers are concerned with late-glacial and Holocene climate history, two of them using chironomidtemperature transfer functions. Heiri et al. (2015) show how discontinuous chironomid-based summer temperature reconstructions from different sites in the Alpine region can be combined to produce a single continuous regional palaeotemperature reconstruction for the region. They present a methodology for combining records that includes an altitudinal temperature correction, a procedure to interpolate individual records to equal time intervals, a procedure to stack records that covers the same time interval and a splicing procedure to combine the stacked records. The authors argue that the approach has the potential to generate accurate regional temperature reconstructions but is currently limited by the number and distribution of individual records.

Self et al. (2015) use a chironomid-temperature transfer function to reconstruct late Holocene temperature for three sites in arctic western Siberia, a hitherto poorly studied region of Arctic Russia. The results indicate that $c .3400$ years ago, July temperatures were $c .1 .5^{\circ} \mathrm{C}$ higher than the present and show a trend in timing and in scale similar to other northern hemisphere records. The data also show significant changes over the last 50 years that the authors suggest might be caused by climate-driven changes in catchment hydrology.

The third paper concerned with climate history (Karmakar et al., 2015) describes the use of diatom records from the sediments of two lakes in northwest Ontario, Canada, to reconstruct aridity history during the mid-Holocene. The lakes are located close to the climatically sensitive prairie-forest ecotone, and within the lakes, the cores were taken from locations close to the presentday planktonic to benthic (P-B) diatom boundary. The authors argue that this location allows the $\mathrm{P}-\mathrm{B}$ ratio in the sediment cores to be used to indicate changes in lake-water level more sensitively than cores taken from the central basin in the deepest water. In the cores from both lakes, the benthic diatom taxa predominate in the early to mid-Holocene period and indicate that lake levels may have been $c .2-5 \mathrm{~m}$ lower than present at that time. The data not only support evidence for a mid-Holocene period of aridity but also indicate the sensitivity of the region to drought should future climate change lead to reductions in effective moisture. 


\section{Human impact on terrestrial and freshwater ecosystems}

Throughout his career, John Birks has been concerned with the role of palaeoecology in understanding how terrestrial and freshwater ecosystems have changed during the Holocene as a result of human activity. The final section of this special issue includes five papers on this theme.

Åkesson et al. (2015) use pollen analysis of two cores from a small lake in south-east Sweden to reconstruct changes in vegetation cover over the Holocene. They use the Regional Estimates of VEgetation Abundance from Large Sites (REVEALS) model to correct for biases related to difference in pollen production and dispersal distance between pollen types and argue that uncorrected pollen percentages significantly underestimate the degree of landscape openness created by long-term farming.

Bradshaw et al. (2015) also use pollen analytical data. They show that biodiverse oak and beech woodlands in the United Kingdom and Sweden of high conservation value, often assumed to be of great antiquity, have all been significantly altered by human activity over recent centuries. They conclude that the currently recognised conservation value of these sites is not necessarily related to their antiquity and that the diversity of insects, fungi, lichens and bryophytes of high conservation value in these forests is more dependent on habitat diversity rather than the longevity of the primary forest.

Boyle et al. (2015) examine the relationship between modelled catchment phosphorus (P) flux and the calculated sediment $\mathrm{P}$ accumulation rate for Hatch Mere, a small English lake, over the Holocene period. They show that there is an excellent agreement between the two in the early Holocene when the model is driven only by climate and the apatite content of catchment soils. However, in the later Holocene, as forests are cleared and farming is introduced, the relationship breaks down. The authors show that the enhanced P flux through the Holocene is proportional to human population density and the model can be adjusted successfully to take account of the effect. They suggest, conversely, that lake sediment $\mathrm{P}$ flux may provide a novel method for estimating local population density in the past.

The final two papers are concerned with Anthropocene timescales and air pollutants. Oldfield et al. (2015) promote the use of the magnetic record of inorganic fly ash in lake sediments and ombrotrophic peats as a stratigraphic marker for the start of the Anthropocene. Inorganic fly ash is generated mainly by solid fuel combustion and metal smelting. From sites in the United Kingdom, Scandinavia and North America, the authors show that the profiles of magnetic measurements compare well with known local records of industrial development. For lake sites in the United Kingdom, the increases in the magnetic record date from the late 19th century to the first decades of the 20th century. The authors caution, however, that attempts to use the magnetic record to mark the start of the Anthropocene would require a careful choice of site and need to take into consideration the potential problem of selective magnetic mineral dissolution in sediments and peats.

The final paper, by Battarbee et al. (2015), describes air pollutant contamination and acidification of a small moorland pool in the North York Moors, UK. It is a multi-proxy study reminiscent of the studies conducted in the SWAP project that John Birks was so intimately involved in (see above and (Birks et al., 1990a). Here, the authors use a range of geochemical and palaeoecological analyses to resolve the argument whether surface waters in the North York Moors were acidified by acid deposition or were naturally very acidic. Despite its very small size the pool, thought to have formed in an abandoned peat cutting, is shown to contain a short but high quality recent sediment record. The authors conclude that the exceptionally acidic nature of the pool is the result of a long history of acid deposition and that the lack of evidence for significant recovery, despite the major reductions in the emissions of acidic gases that have taken place over the last $c .30$ years, indicates the continuing influence of pollutant sulphur stored in catchment peats, a legacy of over 150 years of acid deposition.

\section{Funding}

This research received no specific grant from any funding agency in the public, commercial or not-for-profit sectors.

\section{References}

Adam P (1976) Plant Sociology and Habitat Factors in British Saltmarshes. Cambridge: University of Cambridge.

Åkesson C, Nielsen AB, Broström A et al. (2015) From landscape description to quantification: A new generation of reconstructions provides new perspectives on Holocene regional landscapes of SE Sweden. The Holocene 25(1). DOI: $10.1177 / 0959683614556552$.

Ammann B, Birks HJB, Brooks SJ et al. (2000) Quantification of biotic responses to rapid climatic changes around the Younger Dryas - A synthesis. Palaeogeography, Palaeoclimatology, Palaeoecology 159: 313-347.

Ammann B, Birks HJB, Drescher-Schneider R et al. (1993) Patterns of variation in late-glacial pollen stratigraphy along a northwest - Southeast transect through Switzerland: A numerical analysis. Quaternary Science Reviews 12: 277-286.

Anonymous (1977) Flora Europaea - Sonderheft of the Tea Phytologist. Anniversaire edition. Cambridge: Cambridge University Botany School Tea Club.

Battarbee RW and Renberg I (1990) The Surface Water Acidification Project (SWAP) Palaeolimnology Programme. Philosophical Transactions of the Royal Society of London Series B: Biological Sciences 327: 227-232.

Battarbee RW, Grytnes J-A, Thompson R et al. (2002a) Comparing palaeolimnological and instrumental evidence of climate change for remote mountain lakes over the last 200 years. Journal of Paleolimnology 28: 161-179.

Battarbee RW, Thompson R, Catalan J et al. (2002b) Climate variability and ecosystem dynamics of remote alpine and arctic lakes: The MOLAR project. Journal of Paleolimnology 28: 1-6.

Battarbee RW, Turner S, Yang H et al. (2015) Air pollutant contamination and acidification of surface waters in the North York Moors, UK: Multi-proxy evidence from the sediments of a moorland pool. The Holocene 25(1). DOI: 10.1177/0959683614556380.

Beales PW (1976) Palaeolimnological Studies of a Shropshire Mere. Cambridge: University of Cambridge.

Bennett KD (1982) Tree Population History in the Flandrian of East Anglia. Cambridge: University of Cambridge.

Berglund BE (1986) Handbook of Holocene Palaeoecology and Palaeohydrology. Chichester: John Wiley \& Sons Ltd (reprinted by The Blackburn Press, 2003), 869 pp.

Berglund BE, Birks HJB, Ralska-Jasiewiczowa M et al. (1996) Palaeoecological Events during the Last 15000 Years: Regional Syntheses of Palaeoecological Studies of Lakes and Mires in Europe. Chichester: John Wiley \& Sons Ltd, 764 pp.

Bhagwat SA, Willis KJ, Birks HJB et al. (2008) Agroforestry: A refuge for tropical biodiversity? Trends in Ecology \& Evolution 23: 261-267.

Birks HH (2004) An experiment to improve scientific communication skills amongst Norwegian students. Universitets-pedagogisk utviklingsarbeid i Bergen. Available at: https://bora. uib.no/bitstream/handle/1956/1081/Hilary\%20Birks\%201. pdf? sequence $=1$.

Birks HH (2015) South to North: Contrasting late-glacial and early Holocene climate changes and vegetation responses between south and north Norway. The Holocene 25(1). DOI: $10.1177 / 0959683614556375$. 
Birks HH and Birks HJB (2006) Multi-proxy studies in palaeolimnology. Vegetation History and Archaeobotany 15: 235-251.

Birks HH and Birks HJB (2013) Vegetation responses to late-glacial climate changes in western Norway. Preslia 85: 215-237.

Birks HH, Battarbee RW and Birks HJB (2000) The development of the aquatic ecosystem at Kråkenes Lake, western Norway, during the late glacial and early Holocene - A synthesis. Journal of Paleolimnology 23: 91-114.

Birks HH, Birks HJB, Flower RJ et al. (2001) Recent ecosystem dynamics in nine North African lakes in the CASSARINA project. Aquatic Ecology 35: 461-478.

Birks HH, Jones VJ, Brooks SJ et al. (2012a) From cold to cool in northernmost Norway: Lateglacial and early Holocene multi-proxy environmental and climate reconstructions from Jansvatnet, Hammerfest. Quaternary Science Reviews 33: $100-120$.

Birks HJB (1964) Chat Moss, Lancashire. Memoirs and Proceedings of the Manchester Literary and Philosophical Society 106: 1-24.

Birks HJB (1969) The Late Weichselian and Present Vegetation of the Isle of Skye. Cambridge: University of Cambridge.

Birks HJB (1973) Past and Present Vegetation of the Isle of Skye: A Palaeoecological Study. Cambridge: Cambridge University Press.

Birks HJB (1977a) Modern pollen rain and vegetation of the St Elias Mountains, Yukon Territory. Revue Canadienne De Botanique [Canadian Journal of Botany] 55: 2367-2382.

Birks HJB (1977b) The Flandrian forest history of Scotland: A preliminary synthesis. In: Shotton FW (ed.) British Quaternary Studies: Recent Advances. Oxford: Oxford University Press, pp. 119-135.

Birks HJB (1980a) Modern pollen assemblages and vegetational history of the moraines of the Klutlan Glacier and its surroundings, Yukon Territory, Canada. Quaternary Research 14: $101-129$.

Birks HJB (1980b) Quaternary vegetational history of west Scotland. Unpublished Excursion Guide, Cambridge, 85 pp.

Birks HJB (1980c) The present flora and vegetation of the moraines of the Klutlan Glacier, Yukon Territory, Canada - A study in plant succession. Quaternary Research 14: $60-86$.

Birks HJB (1986) Late-Quaternary biotic changes in terrestrial and lacustrine environments, with particular reference to north-west Europe. In: Berglund BE (ed.) Handbook of Holocene Palaeoecology and Palaeohydrology. Chichester: John Wiley \& Sons Ltd, pp. 3-65.

Birks HJB (1996) Scotland. In: Berglund BE, Birks HJB, RalskaJasiewiczowa $\mathrm{M}$ et al. (eds) Palaeoecological Events during the Last 15000 Years: Regional Syntheses of Palaeoecological Studies of Lakes and Mires in Europe. Chichester: John Wiley \& Sons, pp. 95-143.

Birks HJB (2014) A diverse scientific life. Journal of Paleolimnology 51: 113-137.

Birks HJB and Berglund BE (1979) Holocene pollen stratigraphy of southern Sweden - Reappraisal using numerical methods. Boreas 8: 257-279.

Birks HJB and Birks HH (1974a) Studies on bryophyte flora and vegetation of Isle of Skye. 1. Flora (Hepatics and Sphagnum). Journal of Bryology 8: 19-64.

Birks HJB and Birks HH (1974b) Studies on bryophyte flora and vegetation of Isle of Skye. 1. Flora (Mosses). Journal of Bryology 8: 197-254.

Birks HJB and Birks HH (1980) Quaternary Palaeoecology. London: Edward Arnold (reprinted by the Blackburn Press, 2006).

Birks HJB and Birks HH (2004) Paleoecology - The rise and fall of forests. Science 305: 484-485.
Birks HJB and Birks HH (2008) Biological responses to rapid climate change at the Younger Dryas-Holocene transition at Kråkenes, western Norway. The Holocene 18: 19-30.

Birks HJB and Gordon AD (1985) Numerical Methods in Quaternary Pollen Analysis. London: Academic Press.

Birks HJB and Lotter AE (1994) The impact of the Laacher See Volcano (11000 yr BP) on terrestrial vegetation and diatoms. Journal of Paleolimnology 11: 313-322.

Birks HJB and Madsen BJ (1979) Flandrian vegetational history of Little Loch Roag, Isle of Lewis, Scotland. Journal of Ecology 67: 825-842.

Birks HJB and Peglar SM (1979) Interglacial pollen spectra from Sel-Ayre, Shetland. New Phytologist 83: 559-575.

Birks HJB and Willis KJ (2008) Alpines, trees, and refugia in Europe. Plant Ecology \& Diversity 1: 147-160.

Birks HJB, Jones VJ and Rose NL (2004a) Recent environmental change and atmospheric contamination on Svalbard as recorded in lake sediments - An introduction. Journal of Paleolimnology 31: 403-410.

Birks HJB, Jones VJ and Rose NL (2004b) Recent environmental change and atmospheric contamination on Svalbard as recorded in lake sediments - Synthesis and general conclusions. Journal of Paleolimnology 31: 531-546.

Birks HJB, Berge F, Boyle JF et al. (1990a) A palaeoecological test of the land-use hypothesis for recent lake acidification in south-west Norway using hill-top lakes. Journal of Paleolimnology 4: 69-86.

Birks HJB, Line JM, Juggins S et al. (1990b) Diatoms and pH reconstruction. Philosophical Transactions of the Royal Society of London Series B: Biological Sciences 327: 263-278.

Birks HJB, Lotter AF, Juggins S et al. (2012b) Tracking Environmental Change Using Lake Sediments: Data Handling and Numerical Techniques, vol. 5. Dordrecht: Springer, $745 \mathrm{pp}$.

Birks HJB, Monteith DT, Rose NL et al. (2004c) Recent environmental change and atmospheric contamination on Svalbard as recorded in lake sediments - Modern limnology, vegetation, and pollen deposition. Journal of Paleolimnology 31: 411-431.

Bjune AE and Birks HJB (2008) Holocene vegetation dynamics and inferred climate changes at Svanavatnet, Mo i Rana, northern Norway. Boreas 37: 146-156.

Bjune AE, Bakke J, Nesje A et al. (2005) Holocene mean July temperature and winter precipitation in western Norway inferred from palynological and glaciological lake-sediment proxies. The Holocene 15: 177-189.

Bjune AE, Birks HJB, Peglar SM et al. (2010) Developing a modern pollen-climate calibration data set for Norway. Boreas 39: 674-688.

Bjune AE, Grytnes J-A, Jenks CR et al. (2015) Is palaeoecology a 'special branch' of ecology? The Holocene 25(1). DOI: $10.1177 / 0959683614556386$.

Boyle JF, Chiverrell RC, Davies H et al. (2015) Modelling the impact of pre-historic farming on Holocene landscape phosphorus dynamics. The Holocene 25(1). DOI: 10.1177/0959683614556381.

Boyle JF, Rose NL, Appleby PG et al. (2004) Recent environmental change and human impact on Svalbard: The lakesediment geochemical record. Journal of Paleolimnology 31: $515-530$.

Bradshaw EG, Jones VJ, Birks HJB et al. (2000) Diatom responses to late-glacial and early-Holocene environmental changes at Kråkenes, western Norway. Journal of Paleolimnology 23: 21-34.

Bradshaw RHW (1978) Modern Pollen Representation Factors and Recent Woodland History in S.E. England. Cambridge: University of Cambridge. 
Bradshaw RHW, Jones C, Edwards S et al. (2015) Forest continuity and conservation value in Western Europe. The Holocene 25(1). DOI: $10.1177 / 0959683614556378$.

Brooks SJ and Birks HJB (2001) Chironomid-inferred air temperatures from Lateglacial and Holocene sites in north-west Europe: Progress and problems. Quaternary Science Reviews 20: $1723-1741$.

Brooks SJ and Birks HJB (2004) The dynamics of Chironomidae (Insecta: Diptera) assemblages in response to environmental change during the past 700 years on Svalbard. Journal of Paleolimnology 31: 483-498.

Cameron NG, Birks HJB, Jones VJ et al. (1999) Surface-sediment and epilithic diatom $\mathrm{pH}$ calibration sets for remote European mountain lakes (AL:PE Project) and their comparison with the Surface Waters Acidification Programme (SWAP) calibration set. Journal of Paleolimnology 22: 291-317.

Cao X, Herzschuh U, Ni J et al. (2015) Spatial and temporal distributions of major tree taxa in eastern continental Asia during the last 22,000yr. The Holocene 25(1). DOI: $10.1177 / 0959683614556385$.

Cleveland WS, Grosse E and Shyu WM (1993) Local regression models. In: Chambers JM and Hastie TJ (eds) Statistical Models. London: Chapman \& Hall, pp. 309-376.

Cumming BF, Smol JP and Birks HJB (1991) The relationship between sedimentary chrysophyte scales (Chrysophyceae and Synurophyceae) and limnological characteristics in 25 Norwegian lakes. Nordic Journal of Botany 11: 231-242.

Cumming BF, Smol JP and Birks HJB (1992a) Scaled chrysophytes (Chrysophyceae and Synurophyceae) from Adirondack drainage lakes and their relationship to environmental variables. Journal of Phycology 28: 162-178.

Cumming BF, Davey KA, Smol JP et al. (1994) When did acidsensitive Adirondack lakes (New York, USA) begin to acidify and are they still acidifying? Canadian Journal of Fisheries and Aquatic Sciences 51: 1550-1568.

Cumming BF, Smol JP, Kingston JC et al. (1992b) How much acidification has occurred in Adirondack region lakes (New York, USA) since preindustrial times. Canadian Journal of Fisheries and Aquatic Sciences 49: 128-141.

Dalton C, Birks HJB, Brooks SJ et al. (2005) A multi-proxy study of lake-development in response to catchment changes during the Holocene at Lochnagar, north-east Scotland. Palaeogeography, Palaeoclimatology, Palaeoecology 221: 175-201.

Dixit SS, Cumming BF, Birks HJB et al. (1993) Diatom assemblages from Adirondack lakes (New York, USA) and the development of inference models for retrospective environmental assessment. Journal of Paleolimnology 8: 27-47.

Edwards ME (1980) Ecology and Historical Ecology of Oakwoods in North Wales. Cambridge: University of Cambridge.

Eide W, Birks HH, Bigelow NH et al. (2006) Holocene forest development along the Setesdal valley, southern Norway, reconstructed from macrofossil and pollen evidence. Vegetation History and Archaeobotany 15: 65-85.

Felde VA, Peglar SM, Bjune AE et al. (2014) The relationship between vegetation composition, vegetation zones and modern pollen assemblages in Setesdal, southern Norway. The Holocene 24: 985-1001.

Flower RJ and Battarbee RW (1983) Diatom evidence for recent acidification of two Scottish lochs. Nature 305: 130-133.

Franklin-Smith L, Edwards M, Clarke CC et al. (2015) The role of fire in the mid-Holocene arrival and expansion of lodgepole pine (Pinus contorta var. latifolia Engelm. Ex S. Watson) in the Yukon, Canada. The Holocene 25(1). DOI: 10.1177/0959683614556389.

Hargan KE, Rühland KM, Paterson AM et al. (2015) Long-term successional changes in peatlands of the Hudson Bay Lowlands inferred by the ecological dynamics of multiple proxies. The Holocene 25(1). DOI: 10.1177/0959683614556384.

Heegaard E, Lotter AF and Birks HJB (2006) Aquatic biota and the detection of climate change: Are there consistent aquatic ecotones? Journal of Paleolimnology 35: 507-518.

Heggen MP, Birks HH, Heiri O et al. (2012) Are fossil assemblages in a single sediment core from a small lake representative of total deposition of mite, chironomid, and plant macrofossil remains? Journal of Paleolimnology 48: 669-691.

Heiri O, Brooks SJ, Birks HJB et al. (2011) A 274-lake calibration data-set and inference model for chironomid-based summer air temperature reconstruction in Europe. Quaternary Science Reviews 30: 3445-3456.

Heiri O, Ilyashuk B, Millet L et al. (2015) Stacking of discontinuous regional palaeoclimate records: Chironomid-based summer temperatures from the Alpine region. The Holocene 25(1). DOI: $10.1177 / 0959683614556382$.

Helmens KF, Bos JAA, Engels S et al. (2007) Present-day temperatures in northern Scandinavia during the last glaciation. Geology 35: 987-990.

Herzschuh U and Birks HJB (2010) Evaluating the indicator value of Tibetan pollen taxa for modern vegetation and climate. Review of Palaeobotany and Palynology 160: 197-208.

Herzschuh U, Birks HJB, Mischke S et al. (2010a) A modern pollen-climate calibration set based on lake sediments from the Tibetan Plateau and its application to a Late Quaternary pollen record from the Qilian Mountains. Journal of Biogeography 37: 752-766.

Herzschuh U, Birks HJB, Ni J et al. (2010b) Holocene land-cover changes on the Tibetan Plateau. The Holocene 20: 91-104.

Herzschuh U, Ni J, Birks HJB et al. (2011) Driving forces of midHolocene vegetation shifts on the upper Tibetan Plateau, with emphasis on changes in atmospheric $\mathrm{CO} 2$ concentrations. Quaternary Science Reviews 30: 1907-1917.

Herzschuh U, Pestryakova LA, Savelieva LA et al. (2013) Siberian larch forests and the ion content of thaw lakes form a geochemically functional entity. Nature Communications 4: 2408. DOI: $10.1038 /$ ncomms 3408 .

Huntley B (1976) The Past and Present Vegetation of the Morrone Birkwoods and Caenlochan National Nature Reserves. Cambridge: University of Cambridge.

Jacobson GL and Birks HJB (1980) Soil development on recent end moraines of the Klutlan Glacier, Yukon Territory, Canada. Quaternary Research 14: 87-100.

Jones VJ and Birks HJB (2004) Lake-sediment records of recent environmental change on Svalbard: Results of diatom analysis. Journal of Paleolimnology 31: 445-466.

Juggins S (1992) Diatoms in the Thames Estuary, England: Ecology, Palaeoecology, and Salinity Transfer Function (Bibliotheca Diatomologica 25). Berlin: J. Cramer, 216 pp.

Juggins S, Simpson GL and Telford RJ (2015) Taxon selection using statistical learning techniques to improve transfer function prediction. The Holocene 25(1). DOI: $10.1177 / 0959683614556388$.

Karmakar M, Laird KR and Cumming BF (2015) Diatom-based evidence of regional aridity during the mid-Holocene period in boreal lakes from northwest Ontario (Canada). The Holocene 25(1). DOI: 10.1177/0959683614556376.

Kattel GR, Battarbee RW, Mackay AW et al. (2008) Recent ecological change in a remote Scottish mountain loch: An evaluation of a Cladocera-based temperature transfer-function. Palaeogeography, Palaeoclimatology, Palaeoecology 259: 51-76.

Kerslake PD (1982) Vegetational History of Wooded Islands in Scottish Lochs. Cambridge: University of Cambridge.

Kingston JC, Birks HJB, Uutala AJ et al. (1992) Assessing trends in fishery resources and lake water aluminum from 
paleolimnological analyses of siliceous algae. Canadian Journal of Fisheries and Aquatic Sciences 49: 116-127.

Korhola A, Birks HJB, Olander H et al. (2001) Chironomids, temperature and numerical models: A reply to Seppä. The Holocene 11: 615-622.

Lamb HF (1982) The Quaternary Vegetation History of the Forest-Tundra Ecotone in Labrador. Cambridge: University of Cambridge.

Line JM and Birks HJB (1990) WACALIB version 2.1: A computer program to reconstruct environmental variables from fossil assemblages by weighted averaging. Journal of Paleolimnology 3: 170-174.

Lotter AF and Birks HJB (1993) The impact of the Laacher See tephra on terrestrial and aquatic ecosystems in the Black Forest, southern Germany. Journal of Quaternary Science 8: 263-276.

Lotter AF and Birks HJB (1997) The separation of the influence of nutrients and climate on the varve time-series of Baldeggersee, Switzerland. Aquatic Sciences 59: 362-375.

Lotter AF and Birks HJB (2003a) The Holocene palaeolimnology of Sägistalsee and its environmental history - A synthesis. Journal of Paleolimnology 30: 333-342.

Lotter AF and Birks HJB (2003b) Holocene sediments of Sägistalsee, a small lake at the present-day tree-line in the Swiss Alps. Journal of Paleolimnology 30: 253-260.

Lotter AF, Birks HJB and Zolitschka B (1995) Late-glacial pollen and diatom changes in response to two different environmental perturbations - Volcanic eruption and Younger Dryas cooling. Journal of Paleolimnology 14: 23-47.

Lotter AF, Birks HJB, Eicher U et al. (2000) Younger Dryas and Allerød summer temperatures at Gerzensee (Switzerland) inferred from fossil pollen and cladoceran assemblages. Palaeogeography, Palaeoclimatology, Palaeoecology 159: 349-361.

Lotter AF, Birks HJB, Hofmann W et al. (1997) Modern diatom, cladocera, chironomid, and chrysophyte cyst assemblages as quantitative indicators for the reconstruction of past environmental conditions in the Alps. I. Climate. Journal of Paleolimnology 18: 395-420.

Lotter AF, Birks HJB, Hofmann W et al. (1998) Modern diatom, cladocera, chironomid, and chrysophyte cyst assemblages as quantitative indicators for the reconstruction of past environmental conditions in the Alps. II. Nutrients. Journal of Paleolimnology 19: 443-463.

Lotter AF, Eicher U, Siegenthaler U et al. (1992) Late-glacial climatic oscillations as recorded in Swiss lake sediments. Journal of Quaternary Science 7: 187-204.

Nesje A, Bjune AE, Bakke J et al. (2006) Holocene palaeoclimate reconstructions at Vanndalsvatnet, western Norway, with particular reference to the $8200 \mathrm{cal}$. yr BP event. The Holocene 16: 717-729.

Noon PE, Birks HJB, Jones VJ et al. (2001) Quantitative models for reconstructing catchment ice-extent using physical-chemical characteristics of lake sediments. Journal of Paleolimnology 25: 375-392.

Olander H, Birks HJB, Korhola A et al. (1999) An expanded calibration model for inferring lakewater and air temperatures from fossil chironomid assemblages in northern Fennoscandia. The Holocene 9: 279-294.

Oldfield F, Gedye SA, Hunt A et al. (2015) The magnetic record of inorganic fly ash deposition in lake sediments and ombrotrophic peats. The Holocene 25(1). DOI: $10.1177 / 0959683614556379$.

Panizzo VN, Jones VJ, Birks HJB et al. (2008) A multiproxy palaeolimnological investigation of Holocene environmental change, between c. 10700 and 7200 years BP, at Holebudalen, southern Norway. The Holocene 18: 805-817.

Peglar SM (1992) The Development of the Cultural Landscape of East Anglia, U.K. Bergen: University of Bergen.

Pienitz R, Smol JP and Birks HJB (1995) Assessment of freshwater diatoms as quantitative indicators of past climate change in the Yukon and Northwest Territories, Canada. Journal of Paleolimnology 13: 21-49.

Prentice IC (1976) Studies on Modern Pollen Spectra. Cambridge: University of Cambridge.

Renberg I and Hellberg T (1982) The $\mathrm{pH}$ history of lakes in southwestern Sweden, as calculated from the subfossil diatom flora of the sediments. Ambio 11: 30-33.

Rodwell JS (1991-2000) British Plant Communities, vols 1-5. Cambridge: Cambridge University Press.

Rymer L (1974) The Palaeoecology and Historical Ecology of the Parish of North Knapdale. Argyllshire: University of Cambridge.

Seddon AWR, Macias-Fauria M and Willis KJ (2015) Climate and abrupt vegetation change in Northern Europe during the Last Deglaciation. The Holocene 25(1). DOI: $10.1177 / 0959683614556383$.

Self AE, Jones VJ and Brooks SJ (2015) Late Holocene environmental change in arctic western Siberia. The Holocene 25(1). DOI: $10.1177 / 0959683614556387$.

Self AE, Brooks SJ, Birks HJB et al. (2011) The distribution and abundance of chironomids in high-latitude Eurasian lakes with respect to temperature and continentality: Development and application of new chironomid-based climate-inference models in northern Russia. Quaternary Science Reviews 30: $1122-1141$.

Seppä H and Birks HJB (2001) July mean temperature and annual precipitation trends during the Holocene in the Fennoscandian tree-line area: Pollen-based climate reconstructions. The Holocene 11: 527-539.

Seppä H and Birks HJB (2002) Holocene climate reconstructions from the Fennoscandian tree-line area based on pollen data from Toskaljavri. Quaternary Research 57: 191-199.

Seppä H, Birks HJB, Odland A et al. (2004) A modern pollenclimate calibration set from northern Europe: Developing and testing a tool for palaeoclimatological reconstructions. Journal of Biogeography 31: 251-267.

Seppä H, Bjune AE, Telford RJ et al. (2009) Last nine-thousand years of temperature variability in Northern Europe. Climate of the Past 5: 523-535.

Seppä H, Schurgers G, Miller PA et al. (2015) Trees tracking a warmer climate: The Holocene range shift of hazel (Corylus avellana) in Northern Europe. The Holocene 25(1). DOI: $10.1177 / 0959683614556377$.

Smol JP, Birks HJB and Last WM (2001a) Tracking Environmental Change Using Lake Sediments: Terrestrial, Algal, and Siliceous Indicators, vol. 3. Dordrecht: Kluwer Academic Publishers, $371 \mathrm{pp}$.

Smol JP, Birks HJB and Last WM (2001b) Tracking Environmental Change Using Lake Sediments: Zoological Indicators, vol. 4. Dordrecht: Kluwer Academic Publishers, 217 pp.

Smol JP, Wolfe AP, Birks HJB et al. (2005) Climate-driven regime shifts in the biological communities of arctic lakes. Proceedings of the National Academy of Sciences of the United States of America 102: 4397-4402.

Solovieva N, Jones VJ, Nazarova L et al. (2005) Palaeolimnological evidence for recent climatic change in lakes from the northern Urals, arctic Russia. Journal of Paleolimnology 33: 463-482.

Sundqvist HS, Kaufman DS, McKay NP et al. (2014) Arctic Holocene proxy climate database - New approaches to assessing 
geochronological accuracy and encoding climate variables. Climate of the Past 10: 1605-1631.

Ter Braak CJF (1986) Canonical correspondence analysis: A new eigenvector technique for multivariate direct gradient analysis. Ecology 67: 1167-1179.

Vater AE and Matthews JA (2015) Succession of pitfall-trapped insects and arachnids on eight Norwegian glacier forelands along an altitudinal gradient: Patterns and models. The Holocene 25(1). DOI: 10.1177/0959683614556374.

Velle G, Larsen J, Eide W et al. (2005) Holocene environmental history and climate of Råtåsjoen, a low-alpine lake in southcentral Norway. Journal of Paleolimnology 33: 129-153.

Walker IR, Smol JP, Engstrom DR et al. (1991) An assessment of Chironomidae as quantitative indicators of past climate change. Canadian Journal of Fisheries and Aquatic Sciences 48: 975-987.

Wang Y, Herzschuh U, Shumilovskikh LS et al. (2013) Quantitative reconstruction of precipitation changes on the NE Tibetan Plateau since the Last Glacial Maximum - Extending the concept of pollen-source area to pollen-based climate reconstructions. Climate of the Past 10: 21-39.
Williams W (1976) The Flandrian Vegetational History of the Isle of Skye and the Morar Peninsula. Cambridge: University of Cambridge.

Willis KJ and Birks HJB (2006) What is natural? The need for a long-term perspective in biodiversity conservation. Science 314: 1261-1265.

Willis KJ, Bennett KD and Birks HJB (2009) Variability in thermal and UV-B energy fluxes through time and their influence on plant diversity and speciation. Journal of Biogeography 36: $1630-1644$.

Willis KJ, Bailey RM, Bhagwat SA et al. (2010a) Biodiversity baselines, thresholds and resilience: Testing predictions and assumptions using palaeoecological data. Trends in Ecology \& Evolution 25: 583-591.

Willis KJ, Bennett KD, Bhagwat SA et al. (2010b) 4 degrees C and beyond: What did this mean for biodiversity in the past? Systematics and Biodiversity 8: 3-9.

Willis KJ, Feurdean A, Birks HJB et al. (2011) Quantification of UV-B flux through time using UV-B-absorbing compounds contained in fossil Pinus sporopollenin. New Phytologist 192: $553-560$. 